\title{
Paradigmas Tecnológicos e Teorias Econômicas da Firma
}

\author{
Paulo Bastos Tigre
}

Professor do Instituto de Economia da UFRJ

Recebido: fevereiro/2005 Aprovado: abril/2005

\section{ResUmo}

Este artigo analisa a evolução das teorias da firma à luz das mudanças tecnológicas ocorridas em três paradigmas: (i) a Revolução Industrial britânica, que dominou a economia mundial durante todo o século XIX e foi a base de observação para a elaboração da teoria neoclássica; (ii) o paradigma Fordista, que efetivamente deu origem à economia industrial; e (iii) o paradigma das Tecnologias da Informação, cuja construção teórica está baseada, principalmente nas correntes evolucionistas e neo-institucionalistas. A análise da evolução das teorias da firma e sua relação com paradigmas organizacionais distintos mostra que não existe um corpo teórico único e coerente, pois as teorias estão condicionadas por diferentes filiações metodológico-teóricas, enfocam aspectos distintos (produção ou transação) e baseiam-se em contextos institucionais, históricos e setoriais diversos. Conclui que o processo de mudanças tecnológicas e institucionais exige que a teoria evolua continuamente, adotando aportes interdisciplinares e recorrendo mais sistematicamente a pesquisa empírica.

Palavras-Chave | Teorias Econômicas da Firma; Paradigmas Tecnológicos; Evolucionismo; Tecnologias da Informação e Comunicação

Códigos JEL | L10; L20; O33; N60 
ABSTRACT

The structure of the world industry is constantly affected by technological innovations and by an institutional dynamics which destroy and create firms and markets. Historically, the increasing speed of these changes has demanded a continuous reformulation of the economic theories dealing with the firm. This article examines such theories under the analytical framework of technological change in three paradigms: (i) the British industrial revolution which dominated the world economy during the XIX century and was a starting point to the development of the neoclassical microeconomic theory; (ii) the fordist paradigm which gave rise to the industrial economics; and (iii) the information technology paradigm, in which theories are still under development, based mainly on evolutionist and neo-institutionalist frameworks. The analysis of the evolution of the theory of the firm and its relationships with different organizational paradigms shows that theories are based by different methodological affiliations, focus on different aspects (production or transactions) and are based on a diversity of institutional, sectorial and historical contexts.

Kerwords | Economics Theories of the Firm; Tecnological Paradigms; Evolutionism; Information and Comuunications Technologies

JEL-CODES I L10; L20; O33; N60

\section{Introdução}

Ao examinar as teorias econômicas que estudam o funcionamento das empresas e dos mercados, um leitor atento irá se deparar com uma considerável divergência acerca do papel das diferentes forças que influenciam o crescimento e os objetivos das unidades produtivas. A revisão da literatura especializada revela importantes diferenças conceituais, metodológicas e ideológicas entre as três principais correntes teóricas que estudam a firma: neoclássica, organização industrial e evolucionista. O que explicaria estas divergências, além do clássico conflito entre "mercado" versus "intervenção estatal" como motor do desenvolvimento, que divide a ciência econômica desde os tempos de Smith e Marx? 
Este artigo analisa as teorias econômicas da firma sob a ótica do contexto histórico, institucional e tecnológico no qual foram originalmente desenvolvidas. As empresas e organizações não se desenvolvem no vazio, sendo estruturadas a partir de determinados contextos (ou paradigmas) que sofrem sucessivas transformaçôes. As teorias, por outro lado, tendem a estabelecer princípios e modelos estáveis, buscando adquirir um caráter científico essencialmente intemporal e universal. Como afirmam Shapiro e Varian (1999) "a tecnologia muda, mas os princípios econômicos não”. Os economistas são freqüentemente vítimas de suas próprias crenças e comprometimentos com sistemas aceitos de pensamento. Em conseqüência, deixam de avaliar adequadamente o papel de novas variáveis, a exemplo da tecnologia, e relutam em incorporar instrumentais analíticos oriundos de outras correntes do pensamento e áreas da ciência.

Apesar dos economistas reconhecerem que as mudanças tecnológicas e organizacionais são capazes de alterar a estrutura da indústria e o desenvolvimento dos mercados, tais variáveis não foram prontamente incorporadas na teoria econômica tradicional. A grande empresa industrial dominou o cenário econômico por décadas, até que surgissem os primeiros questionamentos teóricos acerca de pressupostos neoclássicos sobre concorrência e deseconomias de escala que, em essência, negavam a própria existência das grandes corporações. A inadequação da teoria marginalista para explicar a estrutura da indústria foi reconhecida somente quando as estatísticas econômicas evoluíram de modo a permitir análises empíricas do grau de concentração da indústria e do aumento da produtividade.

Já do ponto de vista institucional, a organização interna da firma foi observada de forma ainda mais gradual e fragmentada, refletindo a grande complexidade que a observação das empresas apresenta na prática. As indagações sobre a natureza de seu crescimento, objetivos e formas de organização dependeram não apenas de observações empíricas, mas também da acumulação de conhecimentos que deram origem a novos conceitos. $\mathrm{O}$ aporte de teorias oriundas de outras áreas do conhecimento, a exemplo da biologia evolucionista, da psicologia cognitiva e da administração de empresas, permite incorporar dimensões mais sutis e mais difíceis de serem captadas e incorporadas pelas teorias econômicas convencionais. A ortodoxia metodológica da teoria neoclássica limitou a percepção de questões complexas diante da própria limitação de seus instrumentos e variáveis de análise. 
Para compreender a relação teórico-empírica, faremos uma revisão das principais teorias sobre a firma à luz das mudanças tecnológicas ocorridas ao longo de três paradigmas. O primeiro é o da Revolução Industrial britânica, que dominou a economia mundial durante todo o século XIX, sendo a base de observação para a elaboração da teoria neoclássica. O segundo paradigma é o Fordista, surgido nos Estados Unidos e considerado o modelo de organização da produção dominante na maior parte do século XX. Este foi o período em que efetivamente surgiram as teorias da firma e a economia industrial. $\mathrm{O}$ terceiro é o paradigma das Tecnologias da Informação, cujos impactos começamos a vivenciar a partir das décadas de 1970 e 1980 e cuja construção teórica vem evoluindo gradativamente.

A questão de como a teoria tem respondido ao processo de transformação tecnológica e organizacional da firma ao longo do tempo não é trivial, já que não existe um modelo único de firma capitalista. Mesmo em um período de tempo delimitado existem diferentes tipos de firmas e de configuraçôes de mercado coexistindo em um mesmo ambiente econômico. As taxonomias são simples tentativas de classificá-las e agrupá-las segundo determinados critérios de análise, sem pretensão de cobrir toda a diversidade de firmas. Os ambientes culturais, regulatórios e sociais são diferenciados segundo regiōes, países e espaços econômicos unificados. $\mathrm{O}$ fato das teorias se referirem a um objeto real (firmas e mercados) sugere que as diferentes análises estão baseadas, implícitas ou explicitamente, em um "arquétipo" ou tipo ideal de firma e de mercado. Focar a atenção nestes arquétipos significa reconhecer a importância ou simplesmente privilegiar a análise de um tipo dominante ou emergente de firma, sem negar a existência de outros. O foco deste trabalho é como a teoria econômica responde ao processo de inovação tecnológica e organizacional na firmatípica de cada paradigma e aos impactos conseqüentes na concentração do capital.

\section{A teoria neoclássica e a Revolução Industrial britânica}

A teoria neoclássica tradicional, estabelecida a partir dos modelos de equilíbrio geral e parcial, guarda pouca relação com a realidade econômica atual. Sua lógica como modelo abstrato de explicação do funcionamento do mercado nunca chegou a ser abandonada no ensino da microeconomia, dado que não 
se obteve um modelo alternativo que fosse tão fechado e completo. Mas sua aplicação prática para análise de mercados e tomada de decisões nunca logrou muito êxito, apesar das inúmeras tentativas de aperfeiçoar a metodologia utilizada na modelagem econômica e dos esforços para revigorar a teoria com a incorporação de elementos da realidade econômica.

$\mathrm{Na}$ teoria neoclássica tradicional, o foco de interesse permanece vinculado à teoria dos preços e alocação de recursos. A firma é vista como uma "caixapreta”, que combina fatores de produção disponíveis no mercado para produzir bens comercializáveis. O mercado, embora possa apresentar situações transitórias de desequilíbrio, tende a estabelecer condições de concorrência e informaçôes perfeitas. A firma se depara com um tamanho "ótimo" de equilíbrio. As possibilidades tecnológicas são usualmente representadas pela função de produção, que especifica o resultado da combinação possível de fatores. As tecnologias estão disponíveis no mercado, seja através de bens de capital ou no conhecimento incorporado pelos trabalhadores. Por fim, é assumida a racionalidade perfeita dos agentes, diante de objetivos da firma de maximização de lucros.

Neste contexto, a análise interna da firma não constitui uma questão relevante, pois em situação de concorrência perfeita, e na ausência de progresso técnico, a firma teria pouca escolha a fazer. Sua única função é transformar insumos em produtos, e para isso basta selecionar a técnica mais apropriada e adquirir os insumos necessários no mercado, incluindo trabalho e tecnologia. O ambiente competitivo é simples e inerte, praticamente sem incertezas.

Esta imagem de firma do sistema econômico neoclássico está baseada nos princípios de equilíbrio geral estabelecidos pioneiramente por Leon Walras, onde os mercados determinam preços e quantidades produzidas e o empreendedor é considerado apenas um coordenador da produção. A contribuição de Walras, ao construir o modelo matemático de equilíbrio geral, foi tentar ordenar de forma lógica o funcionamento da economia através de uma série de equações simultâneas. Sua preocupação com as leis fundamentais que regem a oferta e a demanda levou-o a adotar uma modelagem matemática onde a firma era apenas um ponto em sua visão sistêmica da economia.

Alfred Marshall (1890), considerado o pai da Economia Industrial, procurou aperfeiçoar o modelo estático walrasiano através das teorias de equilíbrio parcial. Ele não via a economia com suas análises e "leis" como um corpo de 
dogmas imutáveis e universais, mas como "uma máquina para a descoberta da verdade concreta". Marshall tinha em mente um modelo idealizado de funcionamento da firma, derivado de observaçōes casuais, que guardava certa analogia com a realidade das firmas típicas de sua época. Ele não assumiu todos os pressupostos do que hoje se denomina concorrência perfeita, como também não identificou os limites do crescimento das firmas nas deseconomias de escala. Com sólida formação matemática em Cambridge e amplo conhecimento empírico da indústria britânica, Marshall procurou submeter a economia ortodoxa a um rigoroso tratamento científico que até hoje constitui a base da microeconomia tradicional.

Apesar destas importantes constataçōes, a teoria neoclássica tradicional, desenvolvida a partir do início do século XX, acabou dominada pela visão walrasiana que trata a firma como agente individual, sem reconhecê-la como entidade coletiva, dotada de objetivos e regras diferenciadas. Atribui à firma um princípio comportamental único, a maximização do lucro, desconsiderando o princípio de utilidade de cada um dos agentes econômicos. A firma neoclássica apresenta o paradoxo de ser um ator-chave na economia, sem ter uma dimensão correspondente (firma-ponto) e ser passiva (firma autômato). A firma é tratada não como instituição, mas sim como ator, com um status similar ao consumidor individual. Um ator passivo e sem autonomia, cujas funções se resumem em transformar fatores em produtos e otimizar as diferentes variáveis de ação. A natureza das variáveis que a firma manipula não é determinada endogenamente, mas sim pela estrutura de mercado que se impõe a ela. Considerando a disponibilidade de informaçôes, a perfeita capacidade de cálculo e a incerteza probabilizada, a firma se comporta como um autômato, programado uma vez para sempre.

A teoria neoclássica de competição perfeita estava mais preocupada com o sistema de preços do que com competição e organização das firmas. Como afirma Demsetz (1993), a teoria tem origem no debate entre mercantilistas e defensores do livre mercado sobre o papel do Estado na economia. A visão liberal se apoiava na "mão invisível" de Adam Smith, que já no século XVIII apontava para a característica auto-reguladora do sistema de preços. Passado mais de um século, a necessidade de combater aqueles que, a exemplo de Marx, evocavam a necessidade de planejamento central para evitar o caos econômico 
levou os liberais a examinarem mais atentamente as condições necessárias para o sistema de preços funcionar de forma a substanciar os argumentos de Smith. Tais condições foram formalizadas no modelo de competição perfeita.

Assim, chegou-se a um modelo abstrato e descentralizado da economia que, embora sem focar propriamente a firma, tinha por base uma visão do tipo de firma dominante na Revolução Industrial. Até meados do século XX, poucos economistas desenvolveram estudos empíricos sobre a firma. Freeman (1993), resenhando a literatura sobre pensamento econômico e inovação, conclui que a explicação mais comum do negligenciamento histórico dos economistas nas questões empíricas sobre mudanças tecnológicas e organizacionais da firma está centrada na idéia de "caixa-preta", ou seja, de que a mudança tecnológica estaria fora da competência e especialização da maioria dos economistas, sendo, portanto do âmbito profissional de engenheiros e cientistas.

Muitas das hipóteses neoclássicas sobre o comportamento das firmas foram posteriormente criticadas por autores que se defrontavam com realidades empresariais e tecnológicas distintas, nas quais a teoria se mostrava irrealista. Entretanto, observando o ambiente institucional e tecnológico da Revolução Industrial britânica do século XIX, no qual se espelharam Walras, Marshall e seus seguidores, podemos compreender melhor as bases empíricas destas teorias.

Primeiro, é necessário localizá-las histórica e geograficamente. Por volta de 1880, a Grã-Bretanha era responsável por cerca de $40 \%$ das exportações mundiais de produtos manufaturados, contra apenas 6\% dos Estados Unidos. Sua superioridade organizacional e tecnológica se expressava também por uma produtividade do trabalho $14 \%$ maior do que a estadunidense.' Certamente o modelo de operação das firmas típicas desta fase da Revolução Industrial britânica serviu como referencia para as formulações teóricas neoclássicas. Além de mais desenvolvida, a Grã-Bretanha era a pátria da maioria dos autores econômicos da época, o que reforçava ainda mais seu papel de "modelo". Vamos então rever as hipóteses teóricas que parecem espelhar a estrutura desta indústria.

O pressuposto de que as atividades produtivas são coordenadas pelo mercado atomizado, onde nenhuma empresa individualmente tem força bastante para influenciá-lo de forma significante, constitui um dos dogmas neoclássicos mais criticados desde que os oligopólios se tornaram a força dominante dos mercados. 
Entretanto, a empresa industrial britânica típica era de fato de pequeno porte e enfrentava dificuldades institucionais, tecnológicas e organizacionais intransponíveis para crescer. O modelo institucional era a firma-propriedade, gerenciada pelos próprios donos, geralmente uma família ou pequeno grupo de sócios. Restrita pelos seus limitados recursos gerenciais e financeiros, a empresa tendia a ter uma única planta, especializada em uma estreita gama de atividades. Em conseqüência, ele tinha que recorrer ao mercado para obter os insumos necessários e distribuir seus produtos. $\mathrm{O}$ Estado liberal se limitava à manutenção da lei e da ordem e a cumprir funções socais básicas como saúde pública e educação. No tocante à coordenação da atividade econômica, a indústria era deixada ao sabor das forças não reguladas da oferta e da demanda.

O modelo competitivo de pequenas empresas era reforçado por um regime jurídico que atribuía responsabilidade integral dos proprietários pelas dívidas da firma. Em caso de falência, os proprietários respondiam com seus bens pessoais. Embora o regime de sociedades anônimas por cotas já existisse efetivamente, os sucessivos escândalos decorrentes da quebra de empresas limitaram a aceitação pública desta forma de organização legal. O regime de responsabilidade integral limitava o crescimento da firma e evitava a concentração do mercado. Além disso, fomentava o conservadorismo da classe empresarial avessa a riscos que pudessem resultar em sua ruína pessoal.

O uso da escala de produção como fator de aumento da produtividade ainda não despontava como uma estratégia empresarial típica. Por um lado, faltavam recursos técnicos e financeiros para promover investimentos em equipamentos e desenvolver formas de organização que garantissem a produção em massa com qualidade. Por outro, a presença de economias externas em distritos industriais dinâmicos, a exemplo de Manchester, garantia a eficiência coletiva das empresas individuais. As economias externas, como se sabe, derivam da disponibilidade de fatores de produção de baixo custo no mercado, e não de uma melhor utilização dos recursos produtivos no interior da firma. A esse respeito, Marshall observou que as firmas podem usufruir economias externas quando o crescimento de uma indústria permite diluir os custos fixos já investidos na economia como um todo por um volume maior de produção. Ele reconhecia que economias externas podiam ser obtidas com base na coordenação pelo mercado dos fatores de produção (e particularmente dos fatores variáveis 
de produção) adquiridos freqüentemente pela firma. Tais princípios permanecem até hoje adequados para descrever a força de distritos industriais especializados, articulando pequenas e grandes firmas.

Uma questão ainda mais polêmica na teoria neoclássica é a noção de deseconomias de escala. Marshall reconhece as economias de escala proporcionadas pelo uso de maquinaria especializada e atividades administrativas, mas limita tal benefício a algumas indústrias e serviços. Para as demais haveria deseconomias tanto internas quanto externas, em função do aumento dos custos variáveis como trabalho e insumos materiais. Os custos unitários sobem porque o aumento da demanda por insumos variáveis pressiona seus preços no mercado (deseconomias externas) e porque os recursos fixos, como máquinas e administradores, não conseguem interagir com um volume maior de produção com a mesma produtividade (deseconomias de escala internas), dada a dificuldade em garantir qualidade, evitar desperdícios e atrasos e controlar a eficiência da mão-de-obra. Como mostra a curva de custo em forma de "U" dos textos de microeconomia, em algum ponto as deseconomias podem superar as economias de escala.

Observando a informalidade dos princípios organizacionais e a dependência dos recursos externos da firma novecentista, podemos reconhecer o realismo circunstancial dos princípios neoclássicos de deseconomias de escala. $\mathrm{O}$ aumento da produção dependia do aumento da oferta externa de trabalho e matéria-prima, implicando um padrão rígido de localização industrial. A grande concentração regional e setorial da indústria indicava que os empresários dependiam não só da oferta de trabalhadores qualificados como também de uma inserção favorável em uma comunidade de negócios. Especializada em um segmento da cadeia produtiva, a firma precisava de mercados consolidados à jusante e à montante para poder operar eficientemente. À medida que o mercado para um determinado bem se expandia, o crescimento da oferta ocorria, não tanto pelo crescimento das empresas existentes, mas principalmente pela entrada de novas empresas no mercado (Lazonick, 1992).

Apesar dos avanços da automação em determinados segmentos da indústria, havia neste modelo de organização industrial uma "escala típica", determinada pela capacidade nominal dos bens de capital disponíveis no mercado e pelos modelos organizacionais vigentes. Este fato, embora conjuntural, pode ter emprestado certo realismo (ainda que momentâneo) à curva de custo em 
forma de "U". Inovações organizacionais eram pouco freqüentes, na medida que os próprios trabalhadores qualificados eram responsáveis pela definição do processo produtivo. Trabalhadores eram encarregados não só de estabelecer fluxos e rotinas como também de contratar trabalhadores juniores, que eram por eles treinados e supervisionados, reduzindo assim a necessidade de investir em estruturas administrativas. Dada a inexistência de recursos gerenciais que pudessem ampliar os mecanismos de controle, os empresários tendiam a se restringir à operação de uma única planta, facilitando a entrada de concorrentes. As barreiras à entrada não desempenhavam um papel tão importante na estruturação dos mercados. Os empresários se ocupavam mais com operações de compra e venda de insumos e produtos do que com questôes organizacionais internas. $\mathrm{O}$ papel da mudança tecnológica na dinâmica econômica, negligenciado pela teoria neoclássica, era igualmente pouco importante para os empresários britânicos do final do século passado. Ao delegar as inovações aos trabalhadores, a firma (ou o capital) não se apropriava diretamente do conhecimento envolvido na definição do processo produtivo, justificando a hipótese neoclássica de exogeneidade tecnológica. A importância das habilidades detidas pelos trabalhadores para o desenvolvimento industrial era tal que, segundo Landes (1969), a produtividade britânica só foi alcançada pela Europa continental a partir da emigração de mecânicos experientes da Inglaterra para estes países.

O final do século XIX, particularmente o período entre 1873 e 1896, foi um período caracterizado pela deflação, com uma queda média nos preços das commodities de aproximadamente 1/3. A taxa de juros também caiu, a um ponto tal que, segundo Landes (1969:231), os economistas teóricos passaram a admitir a possibilidade do capital ser abundante o suficiente para ser considerado um bem livre. A noção de barreiras à entrada, seja técnica ou financeira, ainda não poderia ser incorporada pelos economistas.

A teoria neoclássica da firma é, apesar de seu aperfeiçoamento, criticada por desconsiderar fatores técnicos e organizacionais em favor de modelos de equilíbrio. A possibilidade de variação infinitesimal da produção, em resposta à variação nos preços e na demanda, é um exemplo de supremacia do lógico em detrimento do empírico. No entanto, outras premissas fundamentais não parecem irrealistas, quando se leva em consideração o funcionamento do modelo industrial de maior sucesso econômico do século XIX. Isso inclui o princípio de 
concorrência (embora não perfeita), do caráter exógeno da tecnologia (incorporada nos trabalhadores e máquinas), do tamanho ótimo de equilíbrio da firma (em um ambiente de mudança tecnológica lenta) e de informaçôes disponiveis (nos redutos privilegiados dos grandes distritos industriais).

Tais fatos, no meu entender, aliados aos precários instrumentos metodológicos, à falta de dados quantitativos disponíveis na época e a uma certa motivação ideológica, podem justificar a direção assumida pelos desenvolvimentos iniciais da teoria neoclássica. Apesar dos esforços para aperfeiçoar e dar mais realismo ao modelo neoclássico, a microeconomia estabelecida sobre estes princípios não logrou alcançar uma compreensão realista da firma moderna. Como justificar, diante da diversidade de estratégia e objetivos empresariais, a hipótese de maximização de lucro? Por que tratar uma entidade coletiva como a firma como um mero agente individual? Como compreender a complexidade que envolve a questão do empreendedor dentro do restrito princípio da racionalidade? Tais questôes ocuparam o pensamento econômico no século seguinte, provocando a divisão da teoria da firma, como veremos a seguir.

\section{Teorias da firma e o Fordismo}

A teoria da firma desenvolve-se verdadeiramente a partir dos anos 1920, com os primeiros questionamentos do realismo e da coerência do modelo neoclássico, abrindo uma nova trajetória teórica, desvinculada de um quadro de referência único e abstrato. Porém, antes de descrever tais desenvolvimentos teóricos, é importante compreender a natureza das transformaçōes tecnológicas e econômicas ocorridas ao longo do século XX. O novo paradigma, estabelecido a partir de inovações técnicas e organizacionais, abriu uma trajetória inteiramente nova para a organização interna da firma e sua interação com o mercado, alterando a dinâmica da acumulação de capital.

A história econômica mostra que as origens e as causas do processo de concentração econômica estão associadas principalmente às inovações tecnológicas e organizacionais. Sylos-Labini (1980), argumenta que o capitalismo industrial se caracterizou por monopólios em muitas das "novas" produções e por um domínio capitalista sobre as corporações de ofícios, através de formas de trabalho por tarefas (putting-out system). A situação se alterou com o 
surgimento das fábricas, dando origem a um sistema concorrencial. Mas a situação mudou novamente a partir do final do século XIX, em função de progressos revolucionários nos meios de comunicação e transporte. $\mathrm{O}$ surgimento do telégrafo, das ferrovias e dos navios a vapor permitiu a unificação de mercados (locais, nacionais e internacionais), destruindo barreiras econômicas assentadas nos altos custos de transportes e criando oligopólios mais estáveis.

Esta visão é compartilhada por Chandler (1990), para quem a origem e o crescimento da grande empresa moderna estão associados a uma cadeia de eventos interligados. O primeiro elo da cadeia foi o cluster de inovações inter-relacionadas que juntas provocaram a revolução no campo dos transportes e das comunicações. A ferrovia e o telégrafo facilitaram um aumento substancial tanto no volume quanto na velocidade da produção. Ao mesmo tempo, as inovações permitiram que determinadas firmas concretizassem a lógica dinâmica do crescimento e competição pela exploração das oportunidades para obter economias de escala e de escopo e para reduzir os custos de transação. Em conseqüência, muitos ramos da indústria se tornaram oligopolistas.

Cabe lembrar que, do ponto de vista econômico, a inovação em si, ou seja, a primeira aplicação comercial de uma invenção, pode não representar impactos significativos. Muito mais importante são a velocidade e a abrangência da difusão destas inovações na economia. A difusão de inovações depende de um conjunto de fatores condicionantes favoráveis, incluindo inovaçôes complementares, criação de infra-estrutura apropriada, quebra de resistência de empresários e consumidores, mudanças na legislação e aprendizado na produção e uso de novas tecnologias. Assim, embora a inovação abra oportunidades para empresas crescerem, criarem mercados e exercerem um poder monopolista temporário, somente sua difusão ampla tem impacto macroeconômico.

Além das revoluções nos transportes e comunicações, três sistemas de inovações contribuíram para alterar a estrutura da indústria, gerando novos modelos de firmas e mercados: a eletricidade, o motor a combustão e as inovações organizacionais fordistas-tayloristas. Tais inovações contribuíram também para mudar o centro dinâmico do capitalismo para os Estados Unidos e, em menor escala, para a Alemanha e a França.

A eletricidade levou quase um século para se difundir como a principal fonte de energia industrial, desde a invenção do telégrafo elétrico em 1840 até 
a quase completa substituição dos motores a vapor e outras fontes de energia primária na indústria dos Estados Unidos por volta de 1930 (Ayres, 1984). Uma série de inovações complementares foi necessária para viabilizar os investimentos na construção de uma complexa infra-estrutura de geração e distribuição. Uma vez difundida, a eletricidade contribuiu para a concentração industrial de duas formas distintas.

Primeiro, as novas fontes de energia permitiram a exploração mais ampla das economias de escala, através do desenvolvimento de máquinas maiores e mais eficientes e de sistemas integrados de produção, a exemplo da linha de montagem. Segundo, a eletricidade permitiu a criação, por inventores-empresários, de grandes firmas inovadoras que praticamente monopolizaram o novo e dinâmico setor produtor de equipamentos de geração, transmissão e aplicação de energia. Os nomes de inventores como Werner Siemens, Alexander Graham Bell, Thomas Edison, Elihu Thompson e George Westinghouse praticamente se confundem com as grandes empresas oligopolistas que passaram, junto a empresas automobilísticas, químicas e de petróleo, a liderar a indústria mundial no século XX. A eletrificação das grandes cidades européias e estadunidenses permitiu a criação da indústria de eletrodomésticos, como máquinas de costura (Singer), aspiradores de pó (Hoover) e ferros elétricos. O setor elétrico já nasceu oligopolizado, pois partiu da exploração de "monopólios temporários", baseados em produtos inovadores que poucas empresas em todo o mundo souberam imitar com sucesso. A entrada nestes mercados exigia elevados investimentos em atividades de pesquisa e desenvolvimento, marketing e serviços que implicavam uma capacidade de organização muito superior à empresa neoclássica da Revolução Industrial britânica.

A invenção do motor a combustão interna, por sua vez, deu origem ao automóvel, ao trator, ao caminhão e ao avião. Embora seus primeiros desenvolvimentos tenham ocorrido na Inglaterra, por volta de 1860, o centro da atividade tecnológica passou para a França e Alemanha. Neste país, o pioneirismo de Nicolaus Otto na produção de motores estacionários a gasolina permitiu o desenvolvimento posterior de veículos autopropulsionados por um grupo de engenheiros que vieram a formar a Daimler-Benz, o primeiro fabricante de automóveis do mundo, hoje líder no mercado de ônibus e caminhões. Ao contrário da indústria de equipamentos elétricos, a indústria automobilística nasceu 
competitiva. No início do século havia nos Estados Unidos cerca de cem fabricantes de automóveis, organizados de forma quase artesanal, configurando uma estrutura da indústria algo próxima da concorrência marshaliana. Poucas décadas depois, graças a inovações organizacionais, a Ford e a General Motors dominavam amplamente o mercado, consolidando um oligopólio que vigora até hoje.

O grande sucesso do motor a gasolina gerou outro gigante do século XX: as empresas petroleiras. A integração vertical das atividades de exploração, transporte, refino e distribuição levaram a Standard Oil Company a se tornar a maior empresa americana no início do século. ${ }^{2} \mathrm{O}$ controle direto de uma ampla gama de recursos produtivos e o domínio que exercia sobre o mercado de petróleo e derivados levou a Suprema Corte a exigir seu desmembramento em 1911, por violação do "Sherman Antitrust Act". A decisão permitiu a formação de outras empresas de petróleo, mas não impediu a consolidação de um oligopólio global conhecido como "as sete irmãs". Fora dos Estados Unidos, a indústria do petróleo só se desenvolveu efetivamente na Inglaterra, graças a seu domínio colonial das regiōes produtoras do Kuwait e Iraque que começaram a produzir em 1908. A estrutura da indústria mundial de petróleo foi condicionada pelas altas barreiras à entrada, erigida pela grande escala e integração vertical da produção, e pelo poderio imperialista e naval estadunidense e britânico.

A terceira área de inovação tecnológica que favoreceu a transformação da firma e do mercado foi a produção em massa, associada a Henry Ford e à indústria automobilística. As origens do sistema de produção em massa podem ser encontradas na obra de Adam Smith, através de suas famosas observações sobre as vantagens da divisão do trabalho em uma fábrica de alfinetes. Tal princípio foi explorado posteriormente por teóricos industriais como Charles Babbage, que comparava a fábrica a uma máquina complexa, com máquinas e trabalhadores especializados em tarefas específicas organizadas de forma sistêmica. Mas foi somente com Frederick Taylor, através de seus Princípios da Administração Científica, publicado em 1911, que as vantagens da economia de escala foram definitivamente demonstradas. Taylor foi consultor de Henry Ford em seu projeto de linha de montagem, combinando os princípios de divisão do trabalho, mecanização do processo, padronização, intercâmbio de peças e administração científica racional.

2 Em 1902, a Standard Oil foi superada pela United States Steel, mas permaneceu no segundo lugar (Chandler, 1962: 164). 
Chandler (1977) destaca duas ondas de inovações organizacionais que romperam os limites ao crescimento da firma. A primeira, ocorrida na virada do século, foi a integração vertical em atividades encadeadas em unidades distintas, a exemplo da indústria do petróleo. A segunda, ocorrida a partir dos anos 1920, foi a organização multidivisional. Ambas contribuíram para viabilizar a administração eficiente da grande corporação, eliminando assim as economias internas de escala. $\mathrm{Na}$ organização multidivisional, um escritório central planeja, coordena e avalia o trabalho de diversas divisões operacionais e aloca pessoal, instalações, capital e demais recursos necessários para realizar a produção. Os executivos responsáveis por estas divisões, por sua vez, têm sob seu comando a maioria das funções necessárias para gerir uma linha de produtos ou serviços em uma ampla área geográfica, sendo responsáveis pela lucratividade de sua divisão e seu sucesso no mercado.

Nas primeiras décadas do século XX, o “capitalismo proprietário" deu lugar ao "capitalismo gerencial" como motor dominante do desenvolvimento econômico (Lazonick, 1992). Inovaçóes organizacionais e tecnológicas permitiam o uso de estruturas gerenciais para planejar e coordenar a produção em larga escala e aplicar conhecimento científico à indústria. $\mathrm{O}$ modelo de capitalismo proprietário se mostrou inadequado para lidar com a crescente complexidade da atividade industrial e os altos custos fixos derivados da produção em massa.

Nos anos 1920, o oligopólio já caracterizava grande parte da indústria manufatureira dos Estados Unidos. Em meados do século, firmas dominantes haviam emergido inclusive em setores tipicamente intensivos em trabalho, como o têxtil. No entanto, o potencial para realização de economias de escala não estava distribuído igualmente em todos os setores. As maiores empresas industriais do mundo estavam concentradas nos ramos de alimentos, química, petróleo, metais primários e os três setores de equipamentos: máquinas elétricas e não-elétricas e material de transporte. A realidade destes setores dinâmicos colocava em xeque as teorias econômicas neoclássicas, exigindo uma ampla revisão dos princípios de concorrência perfeita e deseconomias de escala. No entanto, quase meio século foi necessário entre a emergência da grande corporação e a consolidação de um corpo teórico alternativo que lidasse com as questões de economias de escala, escopo, transaçôes e oligopólio. 
Pietro Sraffa (1926) foi um dos primeiros economistas a assumirem esta missão, ao questionar a noção de rendimentos decrescentes pela sua incompatibilidade com economias de escala. Isso o levou também a criticar a relação entre preços e custos, pois diferentes escalas determinam diferentes custos de produção. Produtores mais eficientes podiam comandar preços menores e/ou maiores lucros, desequilibrando o mercado e provocando concentração. Sraffa levanta a contradição do "dilema de Marshall" - como conciliar concorrência com retornos crescentes de escala? ${ }^{3}$

Joan Robinson (1933) formulou sua teoria da concorrência imperfeita ao perceber o irrealismo da situação de concorrência perfeita, onde nenhum produtor teria individualmente condições de afetar os preços. A evidência empírica das grandes firmas usufruindo economias de escala levou-a a afirmar que cada firma tinha um monopólio para seus produtos, que era resultado da preferência dos consumidores, apesar da existência de substitutos muito próximos produzidos por outras firmas. E. H. Chamberlain desenvolveu idéias similares simultânea e independentemente.

As críticas ao modelo concorrencial levaram à identificação do oligopólio como a forma mais típica de estrutura da indústria. Kaldor (1934) argumenta que "cada vendedor está em concorrência direta somente com outros poucos vendedores e que a cadeia destes grupos oligopolistas compõe todo o mercado. O oligopólio é, na realidade, a condição mais geral”. E. A. Robinson (1931) trabalhou uma teoria da concorrência monopolista dando mais realismo às teorias neoclássicas dos mercados e das firmas. A teoria assume nova dimensão ao deslocar o centro de interesse da questão do equilíbrio das condições de produção e de distribuição de bens e serviços para o estudo do comportamento e das interaçóes entre produtores. Neste contexto, a firma passa a assumir o papel principal, dada a possibilidade de recorrer à diferenciação de produtos e a estabelecer uma política de vendas. Assim, incorporam-se à firma variáveis consideradas exógenas na teoria neoclássica, como a tecnologia e os preços.

As contribuições de Sraffa, Joan Robinson, Chamberlain permitiram reformular a ortodoxia dominante, mas mantiveram o arcabouço estático que caracterizava a economia neoclássica. Segundo Coutinho (1983), a primeira ruptura consistente e bem-sucedida do impasse em que se encontrava a microeconomia 3 Ver Possas (1987:17). 
marshaliana e walrasiana ocorreu somente em 1952, quando Steindl publicou Maturidade e Estagnação no Capitalismo Americano. Ele constrói uma teoria consistente e articulada de acumulação e de concentração apoiada em evidências empíricas sobre estruturas de custos, formação de preços e formas de concorrência em condições de oligopólio em nível de setores industriais. Assim, ao contrário da ortodoxia que estabelecia modelos estáticos e abstratos de comportamento da firma e mercados, Steindl se inspira diretamente na realidade do processo de concorrência de seu tempo, reconhecendo o papel crucial da propaganda, da diferenciação do produto e da inovação tecnológica no processo de acumulação do capital. As assimetrias entre firmas constituem um fator essencial na explicação da configuração e transformação das estruturas de mercado. As empresas com menores custos e margens de lucros maiores são, segundo Steindl, as que têm maiores possibilidades de crescer a longo prazo.

O processo de concentração já havia sido reconhecido pioneiramente por Marx, que considerava a centralização do capital uma tendência histórica do capitalismo. Seguindo este insight, Schumpeter (1942) reconheceu a importância da grande empresa e da concentração da produção para o progresso técnico. A relação entre oligopólio e o progresso técnico é mútua: por um lado, o processo de diferenciação do produto conduzia a expansão e a criação de novos mercados oligopolistas. Por outro, os altos custos de P\&D, necessários para a sobrevivência das empresas nos mercados dinâmicos, exigiam a presença das grandes empresas. Embora a teoria schumpeteriana não tivesse o reconhecimento das correntes principais do pensamento econômico, sua contribuição influenciou progressivamente as teorias da firma, até serem plenamente incorporadas pelo evolucionismo.

O estudo das conseqüências do processo de centralização do capital na organização da firma e do mercado passou a constituir uma área de crescente interesse. $\mathrm{O}$ instrumental analítico se diversificou, passando a incorporar a sociologia, o behaviorismo e ciências do comportamento, além de aperfeiçoar a metodologia empírica. A ruptura com os limites da teoria econômica e com o papel passivo atribuído à firma na microeconomia neoclássica abriu caminho para o desenvolvimento das teorias da firma, como resposta à importância crescente da grande empresa.

A própria existência da firma parecia nebulosa na teoria neoclássica, diante da onipotência atribuída ao mercado. Duas linhas de investigação abordam esta 
questão. A primeira procura explicar a existência da firma em função das falhas do mercado e foi iniciada por Coase (1937), seguida por Williamson (1979) e por autores de novos enfoques neoclássicos (economia de troca).

A segunda linha, influenciada por Marx e Schumpeter, vê a firma como espaço de produção, lugar de criação de riqueza e inovação. Para Coriat e Weinstein (1995), três concepções podem ser identificadas:

(i) firma organização: os behavioristas Simon, Cyert e March vêem a firma como uma ação coordenada entre indivíduos e grupos. Para assegurar a sobrevivência da firma e seus membros tornou-se necessária a conversão do conflito em cooperação, a mobilização de recursos e a coordenação dos esforços;

(ii) firma instituição: segundo Hodgson (1988), os chamados "velhos institucionalistas" vão além da visão organizacional, incorporando a dimensão social (sistema político, social e jurídico na qual a firma se insere e que limita sua metamorfose). Isso inclui sistemas de propriedade, relações com bancos, condições de produção e de mercado;

(iii) custos de transação e os novos institucionalistas: Coase (1937) introduziu novas questôes sobre a natureza da firma, passando a considerá-la uma forma particular de organização econômica, ou seja, um arranjo institucional alternativo ao mercado. A questão fundamental colocada por Coase e, mais tarde desenvolvida por Williamson, é: "por que a firma existe?” Coase criticou a teoria neoclássica por não oferecer resposta ao fato dos mercados não lograrem exercer a coordenação que as firmas fazem internamente. Se assim fosse, "por que uma grande firma não poderia trabalhar tão bem como o mercado?” (Winter, 1993). Além de questionar a capacidade da teoria existente em explicar a organização econômica, Coase critica a falta de realismo e a ênfase no indivíduo como agente econômico, em detrimento da organização (individualismo metodológico). A análise de Williamson sobre integração vertical da produção destaca o potencial de coordenação da firma em função de falhas de transação no mercado, diante da possibilidade de comportamentos oportunistas dos agentes.

A questão dos objetivos da firma ganha interpretações alternativas ao enfoque estático da maximização de lucros a curto prazo. As contribuições de 
Sylus-Labini (maximização de lucros a longo prazo), Baumol (maximização das vendas globais), Marris (maximizar taxa de crescimento das vendas), Joan Robinson (sobrevivência), Galbraith (manutenção do poder da tecnoestrutura), entre outros, abrem espaço para o reconhecimento de que os objetivos da firma podem variar de acordo com os objetivos de seus controladores, sem que se possa imputar uma regra universal. O comportamento único e maximizador foi mais tarde rejeitado pelos novos institucionalistas e autores evolucionistas que concluíram, segundo Pondé (1996), "que a racionalidade substantiva ou maximizadora constitui um suposto irreal e incapaz de modelar sem distorçôes o comportamento dos agentes econômicos, na medida em que os resultados das ações e decisões dependem de eventos futuros que não podem ser antecipados de maneira probabilística”.

Tal discussão nos remete a outra falha da teoria microeconômica e de uma parte considerável da economia industrial, que é sua incapacidade de incorporar o ator central da firma: o empreendedor. A questão foi levantada inicialmente por Dobb (1925), que reconheceu que os empresários são agentes que tomam as decisões dominantes da vida econômica. O mundo neoclássico do cálculo racional não deixava lugar para a iniciativa e a inovação. $O$ papel do empreendedor foi mais tarde trabalhado na teoria econômica em três aspectos fundamentais: a inovação, através do trabalho de Schumpeter (1954); aquisição e exploração da informação pela chamada "escola austríaca", principalmente Hayek (1937) e Kirzner (1973); e organização e coordenação da produção. Inicia-se assim a passagem do equilíbrio estático para uma visão evolucionista que incorpora incerteza e informação.

O processo de crescimento da firma ${ }^{4}$ e oligopolização dos mercados, observado ao longo do século XX, levou as teorias da firma e a economia industrial a incorporarem uma série de contribuiçôes, aproximando-as mais da realidade. É considerada toda uma gama de configurações de mercados, permitindo a elaboração de modelos de comportamento das firmas em situação de oligopólio. A análise das barreiras à entrada e o papel das atividades de P\&D na diferenciação do produto passam a merecer atenção. Apesar de todo este aporte, as teorias acabaram sendo superadas pela nova dinâmica tecnológica que passou a

4 A questão do crescimento da firma, e sua influência na configuração do mercado, mereceu atenção de economistas como Penrose (1959) e Marris (1964) cujas idéias convergem para a conclusão de que não há limite para o crescimento da firma, mas simplesmente restrições a seu crescimento. 
condicionar o sistema econômico a partir do último quartil do século XX. Coriat e Weinstein (1995), revisando as teorias que analisam a "firma instituição", "firma organização" e os "custos de transação", argumentam que não há mudança nos fundamentos teóricos da análise da firma, que permanecem os mesmos do modelo concorrencial, baseados em hipóteses imutáveis. O ambiente da firma passa a ser mais complexo, mas existem condições fundamentais e "dadas" às quais a firma se adapta, a exemplo da tecnologia e das condições de produção. O campo de suas ações é bem mais amplo, mas as firmas ainda são orientadas pelos mesmos princípios de racionalidade. Ela continua sendo fundamentalmente uma caixa-preta que reage mecanicamente ao seu ambiente. Apesar de incorporarem novas idéias, as teorias da firma não romperam radicalmente com a tradição econômica, de forma a acompanhar as mudanças radicais ocorridas na tecnologia e na dinâmica competitiva ao longo do século. Tais limitações levam a uma nova trajetória teórica desenvolvida a partir das idéias-chave de Schumpeter.

\section{O paradigma das Tecnologias da Informação e Comunicação e as novas teorias da firma}

No último quartil do século $\mathrm{XX}$, as empresas passaram por um novo processo de transformações, caracterizado pela incorporação de novos modelos organizacionais mais intensivos em informação e conhecimento. A globalização e a liberalização dos mercados reduziram os espaços econômicos privilegiados, eliminando muito do caráter idiossincrático das diferentes economias nacionais. As Tecnologias da Informação e Comunicação (TIC) têm um papel central neste processo, pois constituem não apenas uma nova indústria, mas o núcleo dinâmico de uma revolução tecnológica. Ao contrário de muitas tecnologias que são específicas de processos particulares, as inovações derivadas de seu uso têm a característica de permear, potencialmente, todo o tecido produtivo.

A microeletrônica está na raiz da maioria das inovações em produtos, processos e técnicas organizacionais introduzidas nos últimos 20 anos. $\mathrm{O}$ microprocessador, desenvolvido pela Intel em 1971, mudou a trajetória tecnológica mundial, até então apoiada no uso intensivo de energia e materiais. Sua difusão, entretanto, exigiu o desenvolvimento de uma nova infra-estrutura, 
baseada nas telecomunicações digitais (cabos óticos, rádio e satélites) que só foram efetivamente completadas nos anos 1990. O aperfeiçoamento do "computador em um único chip" abriu caminho para uma onda de inovações complementares e convergentes, cujo ápice pode ser o advento da internet e do comércio eletrônico, que revolucionaram a organização do sistema produtivo.

Diante das novas trajetórias de organização interna da firma e novas formas de articulação com o mercado, a teoria econômica passou a necessitar de reformulações. A maior fragilidade das teorias da firma e da organização industrial é sua incapacidade de atribuir a importância devida ao papel da mudança tecnológica na configuração da firma e dos mercados. Embora Schumpeter tivesse levantado estes aspectos desde meados dos anos 1950, suas idéias não chegaram a influenciar decisivamente o pensamento dominante de sua época, seja por requererem maior aprofundamento e sistematização, seja por estarem adiante de seu tempo. Foi necessária uma mudança visível e empiricamente comprovável na natureza do processo competitivo mundial para que seu trabalho fosse retomado, através da linha evolucionista ou neo-schumpeteriana. As novas teorias da firma, voltadas para o entendimento deste novo paradigma, ganham força com a análise das empresas japonesas, principalmente pelo trabalho de Aoki e pelas análises históricas de Chandler sobre as inovações organizacionais nas empresas americanas. Esta corrente é freqüentemente chamada de neoinstitucionalista.

\section{A linha neo-schumpeteriana ou evolucionista}

As teorias econômicas conhecidas como evolucionistas ou neo-schumpeterianas constituem a mais bem articulada tentativa de construir um novo corpo teórico para o estudo da firma. Sua origem é dupla: por um lado, Freeman $(1974,1997)$ foi o primeiro a resgatar a contribuição de Schumpeter no sentido de incorporar o progresso técnico como variável-chave do processo evolucionário da firma e do mercado. Freeman recupera, aperfeiçoa e atualiza a teoria dos ciclos longos de Schumpeter, mostrando como a difusão de inovaçôes está no centro dos movimentos cíclicos da economia mundial. Por outro lado, Nelson e Winter (1982) iniciaram uma linha de investigações apoiada em Simon, Schumpeter e idéias transpostas da biologia evolucionista, lançando as bases para a reconstrução das teorias da firma. A corrente evolucionista se encon- 
tra atualmente em pleno desenvolvimento, contando com contribuições de um número crescente de autores.

A transposição de conceitos derivados das "ciências duras", como a física e a biologia, para a economia foi inicialmente proposta por Marshall. Apesar de optar pela mecânica newtoniana, ele acreditava que a analogia mais adequada seria com a biologia, mas considerava esta ciência complexa demais para ser transposta para a economia. "The Mecca of the economist lies in economic biology (...) But biological conceptions are more complex than those of mechanics" (citado em Nelson, 1995).

A linguagem evolucionista ou desenvolvimentista tem sido muito usada por economistas para descrever como a estrutura de uma economia muda ao longo do tempo. Indivíduos e organizações são entidades que "aprendem". Economistas costumam caracterizar certas indústrias como "jovens", outras como "maduras". Mas estas metáforas não derivam propriamente da biologia evolucionista, pois o conceito geral de evolução, adotado pelos economistas, era conhecido antes mesmo de sua aplicação na biologia.

As teorias evolucionistas distinguem-se das teorias neoclássicas e das teorias da organização industrial por descartarem hipóteses básicas do pensamento econômico convencional. Três princípios podem ser destacados como chaves para entender as teorias evolucionistas. O primeiro é que a dinâmica econômica é baseada em inovaçôes em produtos, processos e nas formas de organização da produção. As inovações não são necessariamente graduais, podendo assumir caráter radical causando, neste caso, instabilidade ao sistema econômico. É atribuída grande importância também à interação entre agentes econômicos, articulados em clusters de produção. Os conceitos de "destruição criadora" de Schumpeter, de "paradigmas técnico-econômicos" de Dosi (1982) e Perez e a analogia com a biologia evolucionista de Darwin são esclarecedores da essência descontínua atribuída ao crescimento econômico em função da inovação tecnológica.

O segundo princípio descarta a idéia de racionalidade invariante (ou substantiva) dos agentes econômicos. Tomando por base as idéias de Simon, os evolucionistas (Winter, 1993; Dosi, 1991; Coriat \& Weinstein, 1995) criticam as teorias de racionalidade substantiva que pré-define o comportamento de firmas segundo o princípio da maximização. O conceito de maximização não é considerado útil, pois envolve muitas variáveis que não podem ser, 
a priori, conhecidas pelo empreendedor. Os evolucionistas apontam para a necessidade de desenvolver uma visão da firma constituída de indivíduos distintos e dotada de características cognitivas próprias. A diversidade conduz à idéia de racionalidade procedural, ou seja, de que a racionalidade dos agentes não pode ser pré-definida, pois é resultante do processo de aprendizado ao longo das interaçôes com o mercado e novas tecnologias.

O terceiro princípio se refere à propriedade de auto-organização da firma, como resultado das flutuações do mercado. É rejeitado qualquer tipo de equilíbrio de mercado, conforme proposto pela teoria convencional, na medida em que não é possível alcançá-lo em ambiente coletivo de flutuações de agentes individuais com rotinas e capacitações distintas.

Rejeitando a idéia, defendida até hoje por autores neoclássicos - especialmente aqueles ligados à Escola de Chicago como Friedman, Stigler e Becker -, de que os mercados são dotados da capacidade de eliminar eficazmente as firmas incapazes de se comportar segundo o princípio de maximização de lucros, os evolucionistas propõem, alternativamente, o princípio da pluralidade de ambientes de seleção. Este princípio permite explicar a existência de trajetórias tecnológicas diferentes e a grande variedade de estruturas de mercado e de características institucionais dos ambientes nos quais as firmas evoluem. Tecnologias e estruturas de mercado são consideradas idiossincráticas ao tipo de indústria e à natureza dinâmica das configurações particulares que condicionam o processo competitivo. É necessário, portanto, conhecer a natureza das barreiras à entrada, da regulamentação, do grau de competição e as possibilidades de explorar economias de escala e escopo.

A competitividade de uma empresa em uma atividade particular é definida pelos evolucionistas como um conjunto de competências tecnológicas diferenciadas, de ativos complementares e de rotinas. Tais competências são geralmente tácitas e não transferíveis, conferindo à firma um caráter único e diferenciado. A evolução da firma depende da transformação das competências secundárias em centrais, à medida que surgem oportunidades tecnológicas. $\mathrm{O}$ conceito de competência central, desenvolvido principalmente por Teece, Dosi e Winter, é importante para definir uma firma, explicar por que elas diferem e como elas evoluem. A partir dele foram elaboradas tipologias sobre a "coerência" da firma e suas possíveis estratégias de crescimento: especialização, integração vertical, diver- 
sificação, conglomeração, participação em redes e estratégias “vazias” (apoiadas na subcontratação). Assim, são retomadas importantes questôes da literatura de organização industrial.

A relação entre tecnologia e estrutura da indústria é retomada pelas novas teorias da firma, estabelecendo uma controvérsia com o paradigma "estrutura, conduta e desempenho", que exerceu considerável influência na legislação antitruste dos Estados Unidos. A relação entre estrutura e desempenho já havia sido questionada por Schumpeter que criticou a excessiva preocupação dos economistas contemporâneos com a estrutura dos mercados - concorrência e oligopólio. "O problema visualizado (pelos economistas teóricos) é como o capitalismo administra as estruturas existentes, enquanto que o problema relevante é como ele as cria e destrói." A busca de posiçōes monopólicas não constitui em si uma prática danosa à concorrência, mas o seu móvel principal. Isto tem implicações importantes para as políticas de concorrência, que consideram a estrutura como a variável exógena que condiciona o comportamento e o desempenho das firmas.

A cadeia de causalidade vem sendo redefinida pela literatura econômica, que passou a admitir a influência mútua dos fatores. O desempenho, assim como a conduta, também influencia a estrutura de mercado. A proposta neoschumpeteriana, no entanto, vai além destas relações, associando estrutura de mercado com o ciclo de evolução tecnológica do produto. Nelson (1995) argumenta que antes da emergência de um padrão ou projeto dominante, há pouco P\&D orientado para melhorar o processo produtivo, porque o projeto do produto é instável e o mercado para cada produto é pequeno. Com a emergência de um projeto ou padrão dominante, os lucros derivados da exploração de novas formas de produção poupadoras de custos são consideráveis. Freqüentemente o desenvolvimento de um processo de produção melhor envolve a exploração de economias de escala latentes e o estabelecimento de modos de produção intensivos em capital. $\mathrm{O}$ argumento proposto por Abernathy e Utterback (1975) é que este modelo de evolução tecnológica causa um padrão particular de evolução da firma e da estrutura da indústria. Nos estágios iniciais de uma indústria, firmas tendem a ser pequenas e a entrada no mercado relativamente fácil, refletindo a diversidade de tecnologias empregadas e sua rápida mudança. Contudo, quando um padrão dominante 
emerge, e processos de produção especializados são desenvolvidos, barreiras à entrada começam a crescer e aumentam a escala e o capital necessários para produzir competitivamente.

\section{A visão neo-institucionalista}

A ênfase no papel das novas formas de organização empresarial como fonte de competitividade tem origem nos estudos pioneiros de Chandler (1977), que centra seu interesse nas instituições e nas características específicas da sua estrutura empresarial. As análises históricas têm uma concepção mais concreta de instituições, centrando-se na corporação, na moderna universidade de pesquisas, no sistema financeiro e nas instituiçôes reguladoras da atividade econômica internacional, tais como a Organização Mundial do Comércio - OMC e o Fundo Monetário Internacional - FMI.

A visão institucionalista, segundo North (1990), atribui a performance econômica das nações à natureza de suas instituições. Segundo esta visão, as instituições de hoje guardam fortes conexões com as de ontem; daí a importância da trajetória institucional ou path dependecy. Nenhum arranjo institucional pode ser definido como "ótimo", pois eles são frutos de contingências culturais e políticas típicas de cada país. Em alguns países as instituiçōes se desenvolveram de forma a favorecer o progresso econômico, enquanto em outros países não. $\mathrm{O}$ ambiente institucional determina as oportunidades de lucro, direcionando as decisóes e o processo de acumulação de conhecimentos das organizações, gerando trajetórias virtuosas ou viciosas.

Rosemberg e Birdzell (1986), analisando as condições institucionais históricas que permitiram o surgimento da Revolução Industrial, argumentam que o Ocidente enriqueceu porque rompeu os vínculos com as velhas instituições e deixou o mercado funcionar. As revoluçôes burguesas foram essenciais para construir um novo sistema regulatório e legal que estimulasse a acumulação, a concorrência e a inovação. Foram criados, ao longo do processo de mudanças institucionais, mecanismos para assegurar o cumprimento das leis e para alterá-las de forma a permitir adaptação às transformações econômicas e sociais. Tal processo permitiu que o Ocidente superasse economicamente o Oriente a partir do século XVII na medida em que este ficou preso a instituições feudais e religiosas que engessavam o processo evolutivo. 
A visão institucionalista vem sendo revigorada pelo conceito de Sistema Nacional de Inovaçôes, seguindo uma linha de abordagem iniciada por Freeman (1987) e Lundvall (1988) que vem ganhando contribuiçôes sucessivas da linha neo-schumpeteriana. O principal foco de análise é a interação entre os atores econômicos, sociais e políticos que fortalece capacitações e favorece a difusão de inovações em um determinado país. A literatura neo-schumpeteriana enfatiza que as trajetórias que emergem de um paradigma tecnoeconômico raramente são "naturais", impulsionadas apenas por fatores científicos e tecnológicos externos. Fatores econômicos e sociopolíticos são muito importantes na determinação de trajetórias tecnológicas em diferentes países. O processo de seleção ocorre dentro de um ambiente específico onde a qualidade das instituições técnicas e científicas, das estratégias do setor privado, dos estímulos e financiamento as inovaçôes cumprem papéis fundamentais. O conceito de Sistema Nacional de Inovação vêm sendo aplicado regionalmente, através dos chamados "arranjos produtivos locais".

\section{$\mathrm{O}$ enfoque nas inovações organizacionais}

O sucesso do Japão em implementar uma nova onda de inovações de cunho organizacional nos anos 1970 e 1980 teve profundo impacto sobre os estudos de competitividade. A introdução de técnicas organizacionais como just-in-time, controle da qualidade total e estruturas produtivas mais horizontais e integradas em células, levaram empresas japonesas como a Toyota a desafiar o oligopólio longamente estabelecido nos mercados automobilístico e de bens de consumo duráveis. O novo paradigma é comumente chamado de "toyotista", em oposição ao "fordista".

Em uma economia crescentemente globalizada e competitiva, as empresas se vêem obrigadas a tratar os mercados como transitórios, ou "de moda", nos quais os ciclos do produto são curtos, e a mudança na demanda entre um produto e outro é volátil. Neste contexto, é essencial assegurar total flexibilidade e lead-time ${ }^{5}$ reduzido, através da adoção de novas formas de organização da produção que enfatizem estruturas horizontais, descentralização da produção e uma nova forma de coordenação da força de trabalho, com ênfase 5 Lead-time é o tempo necessário para produzir um produto ou serviço. Quanto menor este tempo, maior a capacidade
da empresa se adaptar a mudanças no mercado sem incorrer em altos custos de estocagem. 
na autonomia, polivalência e distribuição da inteligência. Tais conceitos contrastam com a organização Fordista, assentada na especialização, divisão do trabalho e separação entre a concepção, execução e controle da produção. A necessidade de adaptar o processo produtivo a freqüentes mudanças nas quantidades, mix e desenho de produtos reduz substancialmente as vantagens da coordenação hierárquica. Em conseqüência, cresce também a importância das redes de firmas como forma intermediária de coordenação entre a firma verticalizada e o mercado atomizado.

A análise interna da firma como instituição-chave do capitalismo ganhou importância na nova construção teórica. Aoki $(1988,1990)$ contrastou dois tipos idealizados de empresas, a firma "A" - tipicamente estadunidense e Fordista - e a firma " $\mathrm{J}$ " (japonesa), constatando diferenciais de produtividade a partir dos anos 1980. A opção metodológica de observar o funcionamento interno da firma e focalizar as organizações competitivas emergentes passou a ser um elemento fundamental de análise para superar o tratamento convencional dado à firma pelas teorias de custos de transação. A análise de Aoki está centrada na observação empírica das formas de organização adotadas por ambos os tipos de empresa. Ele elucidou a questão de como a indústria automobilística japonesa foi capaz de superar a indústria estadunidense ao analisar detalhadamente a organização do trabalho, do processo de geração e apropriação de tecnologia, e da relação com clientes e fornecedores na Toyota e General Motors. A comparação de métodos organizacionais e tecnológicos colocou por terra os argumentos puramente econômicos - como taxa de câmbio e salários - adotados tradicionalmente para a explicar a maior competitividade japonesa.

Porter (1993) é outro autor que tem contribuído decisivamente para a aplicação de conceitos da economia industrial na gestão estratégica das empresas. Sua crença na importância da firma, como agente central da competitividade das nações, o leva a afirmar que é mais importante analisar as firmas líderes do que simplesmente olhar o mercado ou as políticas governamentais de cada país.

Cabe destacar aqui a diferença metodológica apresentada pelas diferentes visões da firma. Para Aoki, a exemplo de Chandler e Porter, a unidade de análise é a firma, enquanto para Williamson a análise é centrada nas transações. Estes dois focos não são facilmente integráveis, tornando difícil o desenvolvimento de uma teoria unificada. A organização interna da firma e as transações não 
constituem aspectos de um mesmo problema, mas sim visões diferenciadas sobre os fatores determinantes das estratégias e do crescimento das empresas.

\section{A questão das redes de firmas}

Um dos aspectos mais distintivos do novo paradigma técnico-econômico é o processo de reespecialização das grandes empresas em suas competências centrais. Gradativamente, as corporações abandonam determinadas atividades, consideradas periféricas ou não essenciais para a lucratividade e segurança do negócio, transferindo-as a terceiras empresas. A terceirização constitui-se em um processo de transferência de funções ou atividades de uma empresa de origem para uma empresa ou trabalhador (Kon, 2004:125). Em decorrência, celebra-se o surgimento de "redes de firmas" onde as relações entre os participantes freqüentemente são pautadas por relações de longo prazo e pelo comprometimento mútuo dos parceiros com investimentos em ativos específicos e padrões operacionais compatíveis ao longo da cadeia produtiva.

As novas redes de firmas são estabelecidas a partir de relações contratuais formais entre agentes dispersos geograficamente, definidos em função de competências complementares, sem necessariamente um histórico de laços comerciais. Tal forma de organização do processo produtivo contrasta com o modelo típico de estrutura industrial fordista que vigorou nos principais mercados mundiais na maior parte do século XX. As corporações caracterizavam-se pela verticalização da produção, dedicando-se a desenvolver internamente todas as etapas da produção visando assegurar um fluxo de produção eficiente e harmônico ao longo da cadeia produtiva. "Do pinheiro ao livro", slogan adotado nos anos 1950 pela Editora Companhia Melhoramentos, de São Paulo, ilustra a valorização atribuída à integração vertical.

A substituição do mercado atomizado pelo planejamento no âmbito de uma única grande empresa foi um fato explorado por Coase (1937) para criticar a teoria neoclássica que considerava o mercado como a única forma viável de organização da produção. Em seu provocativo artigo entitulado "Por que a firma existe?", Coase argumenta que se o mercado fosse tão eficiente como propunham os economistas ortodoxos, a economia prescindiria de arranjos institucionais alternativos como a grande empresa. Mais tarde Williamson (1979) retoma este tema atribuindo a integração vertical da produção à necessi- 
dade de coordenação do processo produtivo. Para ele, a grande firma hierarquizada seria uma resposta às falhas de transação no mercado, diante da possibilidade de comportamentos oportunistas dos agentes. As redes de firmas seriam formas híbridas de governança entre o mercado atomizado e a grande empresa hierarquizada.

\section{O enfoque da economia da informação e do conhecimento}

Desde que Alvin Tofler publicou $O$ Choque do Futuro, há cerca de 40 anos, as TICs vêm sendo destacadas como instrumentos de transformação econômica e social. $\mathrm{O}$ uso crescente da internet em atividades comerciais a partir de meados da década de 1990, representou um novo ponto de inflexão em direção à chamada "economia do conhecimento". A possibilidade de integrar cadeias globais de suprimentos, aproximar fornecedores e usuários e acessar informações on-line em multimídia onde quer que elas se encontrem armazenadas, deu uma nova dimensão ao processo de transformação. A combinação de fatores dinâmicos como inovação, desenvolvimento de novas aplicações e crescente competição vem contribuindo para a redução de custos, viabilizando o crescimento e a expansão das TICs não só em nações desenvolvidas como também em países em desenvolvimento.

$\mathrm{O}$ uso crescente da internet em atividades comerciais representou um novo ponto de inflexão em direção à chamada "economia do conhecimento". A possibilidade de integrar cadeias globais de suprimentos, aproximar fornecedores e usuários e acessar informações on-line em multimídia onde quer que elas se encontrem armazenadas, deu uma nova dimensão ao processo de transformação. A combinação de fatores dinâmicos como inovação, desenvolvimento de novas aplicações e crescente competição vem contribuindo para a redução de custos, viabilizando o crescimento e a expansão das tecnologias da informação e comunicação não só em nações desenvolvidas como também em países em desenvolvimento.

O impacto das TICs sobre a economia e a sociedade tem trazido à tona conceitos que procuram caracterizar novas formas de organização da produção, fontes de competitividade, e as demais transformações em curso no ambiente social e produtivo. Cabe inicialmente esclarecer os conceitos de informação e conhecimento. A informação se refere a dados codificados, enquanto que o 
conhecimento envolve principalmente aspectos tácitos. O conhecimento é fundamental para se ter acesso à informação, devido à natureza da codificação lingüística, técnica ou científica exigida para sua manipulação e transmissão. Por exemplo, um livro escrito em chinês contém informaçôes que não poderão ser transformadas em conhecimento por pessoas que não dominam este idioma. Neste sentido, Hilbert e Katz (2002) sustentam que conhecimento envolve "habilidades". O conhecimento tácito de um trabalhador pode ser descrito como "capital humano". Ele pode ser, em alguns casos, codificado (por exemplo, em um manual de operações) transformando-se assim em informação.

O termo "economia do conhecimento" vem sendo crescentemente empregado por autores e organismos internacionais enfatizando uma concepção na qual o conhecimento é considerado um insumo mais importante que terra, capital ou trabalho para o processo produtivo moderno. Uma economia baseada no conhecimento se apóia efetivamente na habilidade de gerar, armazenar, recuperar, processar e transmitir informações, funções potencialmente aplicáveis a todas as atividades humanas.

A exploração do potencial aberto pela economia do conhecimento, entretanto, requer condições que nem sempre estão disponíveis em países menos desenvolvidos. As tecnologias da informação permitem uma crescente codificação do conhecimento representando uma janela de oportunidade para sua difusão internacional. Por outro lado, seu uso eficiente depende de conhecimento tácito incorporado no capital humano, aprendizado e desenvolvimento organizacional. Para Soete (2004) "the knowledge divide is more than ever linked to human capital or tacit knowledge". Neste contexto, a exploração do potencial das TICs depende cada vez mais da qualidade das instituições nacionais, da gestão do conhecimento nas empresas, do nível do capital humano e das instituições de ensino e do investimento sistêmico na infra-estrutura do conhecimento.

A importância do papel do usuário para o desenvolvimento tecnológico está relacionada a sua contribuição para o aperfeiçoamento dos produtos (learning by using) e a definição das características da tecnologia. A literatura sustenta que o papel do usuário nas inovações está longe de ser passivo, fato que induz a necessidade de capacitação. Projetistas costumam desenvolver produtos e serviços assumindo (mesmo que de forma implícita) que suas próprias preferências 
coincidem com as dos usuários. Este fato ajuda a entender porque determinadas tecnologias, desenvolvidas segundo um padrão de gostos e/ou custos de produção típicos de um determinado país não são facilmente transferíveis para outros países.

\section{Conclusão}

A análise da evolução das teorias da firma e sua relação com paradigmas organizacionais distintos permite concluir que não existe um corpo teórico único e coerente. As teorias estão condicionadas por diferentes aspectos, cabendo destacar a filiação metodológico-teórica, o aspecto da firma analisado (produção, transação) e o objeto da análise em si (indústrias e contextos institucionais e históricos).

\section{QUADRO 1}

Teorias da firma, estrutura da indústria e sistemas regulatórios em três paradigmas tecnoeconômicos

\begin{tabular}{|c|c|c|c|}
\hline & $\begin{array}{l}\text { Revolução Industrial } \\
\text { britânica }\end{array}$ & Fordismo & $\begin{array}{l}\text { Paradigma } \\
\text { da informação }\end{array}$ \\
\hline $\begin{array}{l}\text { Principais correntes } \\
\text { teóricas da firma }\end{array}$ & Neoclássica & Economia Industrial & $\begin{array}{l}\text { Evolucionistas } \\
\text { neo-institucionalistas }\end{array}$ \\
\hline Preocupações centrais & $\begin{array}{l}\text { - Equilíbrio } \\
\text { - Racionalidade perfeita } \\
\text { dos agentes } \\
\text { - Ênfase na análise das } \\
\text { relações de troca } \\
\text { (firma caixa-preta) }\end{array}$ & $\begin{array}{l}\text { - Estrutura de mercado } \\
\text { - Economias de escala } \\
\text { - Crescimento da firma } \\
\text { - Racionalidade relativa } \\
\text { - Custos de transação }\end{array}$ & $\begin{array}{l}\text { - Mudança tecnológica } \\
\text { - Instituições } \\
\text { - Cooperação }\end{array}$ \\
\hline $\begin{array}{l}\text { Estrutura da indústria } \\
\text { e organização da } \\
\text { firma }\end{array}$ & $\begin{array}{l}\text { - Pequenas empresas } \\
\text { - Especialização vertical } \\
\text { - Dependência das } \\
\text { economias externas }\end{array}$ & $\begin{array}{l}\text { - Oligopólio } \\
\text { - Empresas multinacionais }\end{array}$ & $\begin{array}{l}\text { - Rede de firmas } \\
\text { - Oligopólio global }\end{array}$ \\
\hline $\begin{array}{l}\text { Características dos } \\
\text { sistemas nacionais } \\
\text { de regulação }\end{array}$ & $\begin{array}{l}\text { - Laissez-faire } \\
\text { - Estado com funções } \\
\text { regulatórias mínimas } \\
\text { - Responsabilidade plena } \\
\text { dos proprietários }\end{array}$ & - Estado intervencionista & $\begin{array}{l}\text { - Desregulamentação } \\
\text { - Globalização }\end{array}$ \\
\hline
\end{tabular}


A filiação metodológico-teórica tem origem não apenas em motivações ideológicas, mas também nas preocupaçôes derivadas da própria estrutura da indústria e da organização da firma. O Quadro 1 sintetiza as principais relaçôes entre teoria e realidade econômica da firma ao longo dos três paradigmas estudados, mostrando que existe certa coerência entre paradigmas tecnoeconômicos e teorias da firma. Isso indica que, mais cedo ou mais tarde, a teoria procura se adaptar à realidade dos padrões dominantes de competição, das características das tecnologias e da organização da produção. Em geral, observa-se uma considerável defasagem entre a realidade e sua apropriação teórica. Como afirma Winter (1993), "nos últimos 50 anos, a economia tem sido muito melhor em mudar a si própria do que os economistas em mudarem suas idéias". Isso ocorre porque as correntes de pensamento muitas vezes se tomam prisioneiras de seus próprios dogmas, deixando de desenvolver criativamente o diálogo com a realidade. Assim, idéias desenvolvidas para um contexto são reproduzidas e (mal) adaptadas para contextos diversos por força de princípios pretensamente universais e atemporais.

As teorias formais, baseadas em metodologias matemáticas, tendem a se prender mais ao arcabouço de suas hipóteses, à custa de um crescente distanciamento da realidade. Elas geralmente têm a pretensão de serem mais "científicas" do que as teorias apreciativas, baseadas na análise histórica e empírica. Esta pseudo-superioridade da formalização fica obscurecida quando aplicada a uma ciência social como a economia, onde o número de variáveis é maior e, em muitos casos, imponderável. A diferença entre as teorias formais e apreciativas, segundo Nelson (1995:50), é apenas uma questão de linguagem, pois ambas são teorias.

O distanciamento não significa que a teoria vá inteiramente a reboque da realidade. Muitos autores, a exemplo de Marx e Schumpeter, foram capazes de identificar características e tendências básicas da organização da produção que só foram amplamente reconhecidas muitos anos após sua publicação. Cabe aqui uma analogia entre inovação e difusão de novas tecnologias. As novas idéias, a exemplo das inovações tecnológicas, não alcançam sucesso enquanto não surgem condições econômicas, sociais e inovações complementares adequadas à sua aceitação. Assim, a tendência concentradora da economia capitalista apontada por Marx ainda no século XIX precisou de algumas décadas e evidências empíricas para ser reconhecida. Schumpeter, por sua vez, precisou de uma nova revolução tecnológica (ocorrida décadas depois de seu falecimento) para ter sua teoria sobre 
o papel da tecnologia sobre o desenvolvimento resgatada e aperfeiçoada pela ciência econômica. A teoria incorporou seus postulados quando estes se tornaram úteis para analisar uma nova realidade estabelecida.

Quanto ao aspecto ou foco da análise, a complexidade e multiplicidade de facetas que o estudo da firma pode assumir tornam quase impossível o desenvolvimento de uma teoria completa e coerente. Corpos teóricos são influenciados por uma visão particular da realidade e carregam o peso de preocupações diferenciadas. Assim, enquanto uma corrente está preocupada em analisar a organização interna da firma, outra está focada nas transaçōes e interações com o mercado. Cabe lembrar que a análise destes aspectos está assentada em diferentes áreas do conhecimento, combinando métodos e conceitos que transcendem o âmbito da economia. Os aspectos relacionados à organização da produção são originalmente objeto de estudo das áreas de engenharia da produção e administração de empresas; as relações industriais e mecanismos de incentivo são um campo de estudo compartilhado com os sociólogos; o estudo da inovação e da difusão de tecnologia está assentado na contribuição de especialistas em tecnologias, enquanto as políticas públicas partem do aporte teórico dos cientistas políticos. O desenvolvimento teórico da firma depende, portanto de uma maior abertura para múltiplas disciplinas.

Por fim, o objeto da análise constitui outro complicador para a formulação de uma teoria unificada da firma. Não existe um modelo único de firma capitalista. Mesmo em um período de tempo delimitado existem diferentes tipos de firmas, indústrias e mercados coexistindo em um ambiente econômico. A idéia de "paradigma" contribui para estabelecer padrões de comportamento e identificar tecnologias-chave. Os paradigmas, no entanto, são apenas visões idealizadas de modelos organizacionais e tecnológicos dominantes em certos períodos de tempo. Os novos paradigmas se desenvolvem mais rapidamente em certos países e setores econômicos do que em outros. Sua difusão é geralmente assimétrica, resultando na heterogeneidade econômica. Este aspecto reforça ainda mais a necessidade de recorrer ao trabalho empírico para entender firmas e mercados. 


\section{Referências bibliográficas}

Abernathy,W.; Utterback, J., "A Dynamic Model of Process and Product Innovation”, Omega, in International Journal of Management Science, 3 (6), p.639-656, 1975.

Aoki, M., Information, Incentives and Bargaining in the Japanese Economy, Cambridge University Press, 1988.

, "Towards and Economic Theory of the Japanese Firm", in Journal of Economic Literature, mar., v.26, 1, 1990.

Ayres, R., The Next Industrial Revolution: Reviving Industry Through Innovation, Cambridge, Mass.: Ballinger Publishing Company, 1984.

Baumol, W., Business Behaviour, Value and Growth, Nova York: Macmillan, 1959.

Chamberlain, E.H., The Theory of Monopolistic Competition, Cambridge, Mass.: Harvard University Press, 1933.

Chandler, A., Strategy and Structure: chapters in the history of the American Industrial Enterprise, in the MIT Press, 1962.

The Visible Hand. The Managerial Revolution in American Business, Cambridge, Mass.: Harvard University Press, 1977.

Scale and Scope: The Dynamics of Industrial Capitalism, Cambridge, Mass.: Harvard University Press, 1990.

Coase, R.H., "The Nature of the Firm", in Williamson, O.; Winter, S., The Nature of the Firm: Origins, Evolution and Development, Oxford University Press, 1937, 1993.

Coriat, B.; Weinstein, O., Les nouvelles theories de l'entreprise, Les Livres de Poche, Librairie Générale Française, 1995.

Coutinho, L., Apresentação, in Maturidade e Estagnação no Capitalismo Americano, São Paulo: Abril Cultural, coleção Os Economistas, 1983.

Demsetz, H., "The Theory of the Firm Revisited", in Williamson, O.; Winter, S., The Nature of the Firm: Origins, Evolution and Development, Oxford University Press, 1993. 
Dobb, M., Capitalist Enterprise and Social Progress, Londres: George Routledge and Sons, Ltd., 1925.

Dosi, G., "Technical paradigms and technological trajectories - a suggested interpretation of the determinants and directions of technical change", in Research Policy, v.11, n.3, 1982.

, "Perspective on Evolutionary Theory", in Science and Public Policy, dez., v.18, p.353-361, 1991.

Freeman, C. (1974), The Economics of Industrial Innovation, Cambridge, MA.: The MIT Press, $3^{a}$ ed., 1997.

, Technology Policy and Economic Performance: lesson from Japan, Londres: Frances, 1987.

, "The Economics of Technical Change: A critical survey article for the Cambridge Journal of Economics, jan. (mimeo), 1993.

Freeman, C.; Lundvall, B-Å. (orgs.), Small countries facing the technological revolution, Londres: Pinter, 1988.

Freeman, C.; Perez, C., "Structural crises of adjustment business cycles and investment behaviour", in Dosi et al., (orgs.), Technical change and economic theory, Londres: Pinter, 1988.

Hayek, F., "Economics and Knowledge", in Economica, 4, 1937.

Hilbert, M. e Katz, J. (2002). Towards a conceptual framework and public policy agenda for the Information Society in Latin América and the Caribbean. UN, CEPAL. Série Desarrollo Productivo, n.133. Disponível em: www.cepal.org/ publicaciones.

Hodgson, G., Economics and Institutions, Cambridge: Polity Press, 1988.

Kaldor, N., "The Equilibrium of the Firm", in The Economic Journal, 44:60-76, 1934.

Kirzner, I. Competition and Entrepreneurship, Chicago: University of Chicago Press, 1973.

Kon, A., Economia de Serviços: Teoria e Evolução no Brasil, Rio de Janeiro: Elsevier, 2004. 
Landes, D., The Unbound Prometheus: Technological change and industrial development in Western Europe from 1750 to present, Cambridge University Press, 1969.

Lazonick, W., "Business organization and Competitive Advantage: Capitalist Transformation in the Twentieth Century", in Dosi, G.; Giannetti, R.; Toninelli, P. (orgs.) Technology Enterprise in a Historical Perspective, Oxford: Claredon Press Oxford, 1992.

Lundvall, B.A., "Innovation as an interactive process: from users-producers interaction to the national system of innovation", in Dosi, G. et al. (orgs.), Technical Change and Economic Theory: Londres, Pinter Publishers, 1988.

Marris, R., The Economic Theory of Managerial Capitalism, Glencoe: Free Press, 1964.

Marshall, A. (1890), Principles of Economics: An Introductory volume, tradução brasileira: Princípios da Economia. São Paulo: Coleção Os Economistas, Abril Cultural, 1982.

Nelson, R., "Recent Evolucionary Theorizing About Economic Change", in Journal of Economic Literature, v.XXXIII, mar., p.48-90, 1995.

Nelson, R.; Winter, S., An Evolutionary Theory of Economic Change, Cambridge: Harvard University Press, 1982.

North, D., Institutions, Institutional Change and Economic Performance, Cambridge: Cambridge University Press, 1990.

Penrose, E. (1959), The Theory of the Growth of the Firm, Oxford: Basil Blackwell, 1980.

Perez, C., Technological Revolutions and Financial Capital, Edward Elgar, 2002.

Porter, M., A vantagem Competitiva das Naçôes, Rio de Janeiro: Editora Campus, 1993.

Possas, M., Estruturas de Mercado em Oligopólio, São Paulo: Hucitec, 1987.

Robinson, E.A., The Structure of Competitive Industry, Londres: Cambridge University Press, 1931.

Robinson, J., Economics of Imperfect Competition, Londres: Macmillan, 1933. 
Rosemberg, N.; Birdzel, L., How the West Grew Rich. Nova York: Basic Books, 1986.

Schumpeter, J., Capitalism, Socialism and Democracy, Londres: George Allen \& Unwin, 1942.

, History of Economic Analysis. Oxford: Oxford University Press, 1954.

Shapiro, C.; Varian, H., A Economia da Informação: como os princípios econômicos se aplicam à era da Internet, Rio de Janeiro: Editora Campus (Título original: Information Rules, Harvard Business School Press), 1999.

Smith, A. (1776), The Wealth of Nation, Penguin Books, 1976, Nova York: Knopf, 1991.

Soete, L., "The Knowledge Economy: Policy Challenges Presentation at the Knowledge Economy Forum III, The World Bank and the Government of Hungary, Improving Competitiveness Through a Knowledge-Based Economy, Budapest, March 23-26, 2004. Disponível em www.worldbank.org/

Sraffa, P., "The law of returns under competitive conditions", in Economic Journal, v.36., 1926.

Steindl, J. (1952), Maturidade e Estagnação no Capitalismo Americano, São Paulo: Coleção Os Economistas, Abril Cultural, 1983.

Sylos-Labini, P. (1964), Oligopólio e Progresso Técnico, Rio de Janeiro ou São Paulo: Forense Universitária, 1980.

Tigre, P., "Inovação e Teorias da Firma em Três Paradigmas", in Revista de Economia Contemporânea, n.3, p.67-111, 1998.

Tofler, A., Future Shock, Londres: Collins, 1968.

Williamson, O., "Transaction Costs Economics: The Governance of Contractual Relations", in Journal of Law and Economics, 22, p.223-261, 1979.

Winter, S., "On Coase, Competence and the Corporation", in Williamson, O.; Winter, S., The Nature of Firm: Origins, Evolution and Development, Oxford University Press, 1993. 